\title{
Groen postkolonialisme in Etosha (Piet van Rooyen)
}

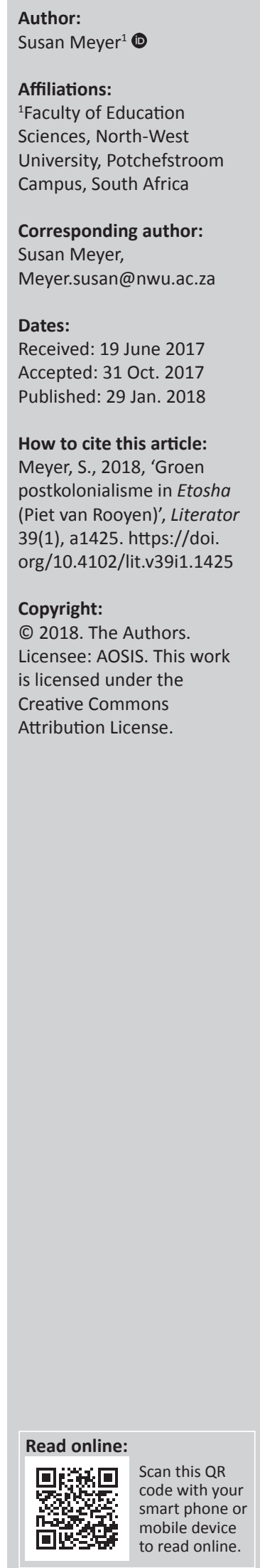

Green postcolonialism in Etosha (Piet van Rooyen). In Etosha (2010) the impact and aftereffect of the colonial system on the Etosha Nasional Park in Namibia, and on the people who lived there, is portrayed. This study explores the situations of various characters and groups who formerly resided there, focusing on aspects of their relationship with one another, as well as on the realities of colonial exploitation and the use or destruction of the natural environment. The question raised is how green postcolonialism takes form in this novel as a result of the convergence of conservation oriented and postcolonial perspectives. The study focuses on the ways Etosha challenges the reader to realise the full complexity of the question, 'Who is actually right, what is justifiable in the battle for survival?', specifically in our local context; and on how the reader is confronted with the task to find place-specific answers for questions aimed at our situation in Africa. It is found that the situations of various role players and their different viewpoints are depicted in a nuanced and convincing manner, contributing to the realistic portrayal of the complex issue of conservation versus exploitation in the postcolonial context. Etosha is a meaningful novel when evaluated within the context of the development of ecocriticism in South Africa.

\section{Inleiding}

In Piet van Rooyen se roman, Etosha (2010), is die Etosha Nasionale Park in Namibië die brandpunt van botsings wat uit die transformasie van natuurbewaring voortspruit. Karel Fechter, die parkhoof, staan in die pad van die regering se planne vir ontwikkeling en vooruitgang. Met sy APU's (Anti-Poaching Unit) probeer hy die park beskerm, onbewus van die wreedaardige wyse waarop die groep oudsoldate sy opdragte uitvoer. Justus Tjambiro is die seun van 'n Himbahoofman wat in die visier van die teenwilddiefstaleenheid beland en met sy lewe moet boet. Die Himbas is, saam met ander inheemse stamme, 'uit ons eie jagveld afgekeer' met die proklamasie van die park deur die destydse Goewerneur van Duits Suidwes-Afrika (Van Rooyen 2010:64). Die renosterhoring wat die hoofman in sy paniekbevange vlugtog laat val, moes vir sy seun se universiteitsopleiding betaal het. In hierdie roman verdien postkoloniale en omgewingskwessies albei dringend aandag.

Enkele jare gelede is daar in 'n LitNet Akademies-webseminaar aan plaaslike akademici in die navorsingsveld van ekokritiek, vrae gestel oor die stand en die belang van ekokritiek in SuidAfrika met verwysing na moontlike rigtings waarin die Suid-Afrikaanse ekokritiek verder kan ontwikkel. Susan Smith (2013) noem as een van die fokuspunte van ekokritiese studies die nadraai en impak wat 'n gewelddadige koloniale bestel gehad het op mense en die plek waar hierdie mense gewoon het. Om 'vir die natuur te lees', beteken vir Smith (2013) om ook te lees 'met 'n bewussyn van die koloniale geskiedenis en hoe ekokritiek en postkoloniale kritiek daartoe meewerk om Afrikagerigte vrae te vra wat Afrikagerigte, plekspesifieke antwoorde tot gevolg kan hê'. Smith (2014) meen dat ekogerigte skryf- en leesaksies tot historiese selfbegrip behoort te lei; dat aandag geskenk moet word aan 'hoe daar in die verlede met plek omgegaan is, hoe gewelddadige strukture van mag en onderdrukking en verskuiwing plek, sowel as sy menslike en niemenslike bewoners beïnvloed het, en hoe daar tans na plek gekyk word'. Ook Visagie (2013) verwys na die toenemende besef by mense in die ontwikkelde wêreld dat die ekokritiek nie verder kan groei sonder om die postkoloniale kontekste van die armer Suide te verreken nie. Visagie (2013) steun op Scott Slovic se standpunt dat die 'essensialistiese en isolasionistiese tendense' wat soms by die ekokritiek insluip, deur insigte vanuit die postkoloniale kritiek teengewerk kan word sodat die persepsie uit die weg geruim kan word 'dat die literatuur oor die omgewing wesenlik oor blomme, voëls en klippe gaan, teenoor die postkoloniale literatuur, wat net mense as fokuspunt het'. ${ }^{1}$

Die sin daarvan om 'n ekologies georiënteerde literêre kritikus in Suid-Afrika te wees, het in die afgelope twee dekades reeds begin blyk uit die navorsing van onder andere Julia Martin (1994),

1.Visagie (2013) gee erkenning aan Bonnie Roos en Alex Hunt wat in die inleidende hoofstuk van Postcolonial green: Environmental politics and world narratives Slovic se standpunt kernagtig aanbied. 
Wendy Woodward (2003), Dan Wylie (2007) en Anthony Vital (2008) - ekokritiese studies waarin die uitgangspunte van die postkoloniale kritiek geïntegreer is. ${ }^{2}$ Steenkamp (2011) beklemtoon die belang en die funksie van 'n plaaslike vorm van ekokritiek waarin sensitiwiteit teenoor die geskiedenis van uitbuiting op sowel die menslike as die omgewingsvlakke weerspieël word:

A localised ecocriticism does not attempt to dismiss the complex and violent history of conservatism in South Africa, but rather suggest ways in which the tension between ecological and humanistic concerns can be negotiated.(p 36)

Heel onlangs word die roman The whale caller van die SuidAfrikaanse skrywer Zakes Mda betrek wanneer Stanley en Phillips (2017) die kritiese vraag vra of die konsep van 'mensgesentreerde' ekokritiek, oftewel een wat bedag is op sensitiewe vrae ten opsigte van hulpbronverdeling, versoenbaar is met kwessies soos die bedreiging van wilde diere waaroor bewaringsgesindes hulle bekommer. ${ }^{3}$ Hierdie artikel word op argumente ten gunste van die integrasie van besorgdhede oor diere, grond en mense gerig; Stanley en Phillips (2017) stel as hulle doelwit die ontrafeling van die skakels tussen bewaring en die sosiale en politieke kwessies gekoppel aan kolonialisme, apartheid en die ongelykhede in die postapartheidsera.

Wat die terrein van die Afrikaanse literatuurteorie en -kritiek betref, kon die proses van die integrasie van postkoloniale en ekokritiese denke nog nie behoorlik op dreef kom nie. Reinhardt Fourie gee die eerste treë in daardie rigting met sy MA-verhandeling (2011), waarin hy Agaat van Marlene van Niekerk ontleed en interpreteer vanuit die gekombineerde vertrekpunte wat die ekokritiek en postkoloniale studies bied. ${ }^{4}$ Susan Meyer (2017) meld wel ook die postkoloniale konteks in Die sideboard as die agtergrond waarteen sy die bestudering van die mensplantverbintenisse in hierdie roman aanpak; sy betrek egter hoofsaaklik die teoretiese beginsels van die ekokritiek in

2. Hoewel Martin reeds in 1987 navorsing gepubliseer het wat 'n ekokritiese fokus verraai, is daar in haar 1994-artikel ' $n$ tendens te bespeur van 'vir die natuur' te lees met gelyktydig ook' $n$ bewustheid van die koloniale geskiedenis.

In Vital se artikel (2008) word J.M. Coetzee se roman Life and times of Michael K (1983) ondersoek as 'n voorbeeld van die verweefdheid van postkoloniale en ekologiese denke. Vir hom is die idee van 'n Afrika-ekokritiek te koppel aan vrae omtrent die spesifieke betekenisse wat plaaslik aan die natuur toegeken word, en oor wat dit omtrent mense hier se hede en verlede verraai (Vital 2008:88).

Wylie (2007) ondersoek die moontlikheid of die verwoording van die Sanwêreldbeskouing, spesifiek die 'ander' waardes, ekologiese strategieë en inheemse kennissisteme soos opgeteken in tekste van Alan James en Antjie Krog, 'n gelokaliseerde basis vir' $n$ Suid-Afrikaanse ekokritiek kan verskaf. Hy beredeneer die betekenisimplikasies daarvan om ' $n$ ekologies georiënteerde literêre kritikus in Suid-Afrika te wees en pas Fernando Oritz se idee van transkulturaliteit toe in ' $n$ poging om ons land se diverse kultuurgeskiedenisse byeen te bring (Wylie 2007:266-267).

Woodward se artikel (2003) val binne die veld van dierestudies en plaas literêre voorstellings van diere binne' $n$ gehistoriseerde kultuur, terwyl sy dit duidelik stel dat ekologieë onlosmaaklik van politiek en kultuur is (Woodward 2003:290). Die werk van drie skrywers van suidelike Afrika, Zakes Mda, Yvonne Vera en Mia Couto, word bespreek om aan te dui op watter wyses hulle koloniale diskursiwiteit omtrent die natuur in hulle postkoloniale tekste weerspreek.

3.Huggan en Tiffin (2007:4) bespreek ook die konflik tussen omgewingsbewaring en menseregte, met verwysing na die feit dat bewaringsmaatreëls onvermydelik op gebiede gefokus is wat nog relatief onaangeraak is deur ontwikkeling. Hierdie gebiede is dikwels ook die streke waar inheemse mense in ' $n$ stryd gewikkel is om hulle lewensbestaan en kultuur teen inbreuk van buite te probeer beskerm.

4.Fourie ondersoek die verhouding tussen sekere romankarakters en plek, spesifiek Grootmoedersdrift, en die aspekte van grond, plantegroei en dierelewe op die plaas. Hy wil vasstel hoe hierdie natuurelemente in die uitbeelding van postkoloniale magsverhoudings tussen die karakters benut word. haar romanontleding. ${ }^{5}$ Navorsing oor die spesifieke betekenisse wat plaaslik, ook in die Afrikaanse letterkunde, aan die natuur toegeken word, is nodig. Navorsing oor wat hierdie gegewens omtrent die hede en verlede van mense hier verraai, is eweneens nodig in die ontwikkeling van 'n verteenwoordigende Suid-Afrikaanse ekokritiek, oftewel 'n omgewingsgerigte literêre studieveld waarin daar vanuit Suid-Afrika en vir Suid-Afrika gelees word.

'n Sinvolle plek in die Afrikaanse letterkunde om na die uitbeelding van die mens-natuurverhouding binne die magsraamwerke van kolonialisme en die postkolonialisme te begin soek, is die oeuvre van Piet van Rooyen. Daar is 'n herhalende tema in sy romans Die spoorsnyer (1994), Agter 'n eland aan (1995) en Die olifantjagters (1997) te vind. Teen die agtergrond van die Namibiese landskap volg die hooffiguur in hierdie romans die spoor van 'n dier, wat aan hom die geleentheid bied om oor die lewensomstandighede van die inheemse bevolkings en die politieke implikasies van koloniale oorblyfsels verslag te doen. ${ }^{6}$ Veral in Die olifantjagters is die problematiek wat aan die orde gestel word in 'n groot mate die voortsetting en die gevolg van kolonialisme. Deurgaans word daarop gesinspeel dat om te jag, is om te oorwin, om Afrika te besit. In hierdie roman word die laaste honderdponder-olifant in Namibië gejag met die doel om geld te genereer en na 'n ontheemde en sukkelende Boesmangemeenskap te kanaliseer. Die kwessie van bewaring versus benutting of uitbuiting van die natuur ten bate van die mens is sterk teenwoordig. Die romantiek van die opheffingsideaal in verband met die Boesmans word uiteindelik nek omgedraai; hulle blyk nie ontvanklik vir die idee van 'n gevestigde lewe met beesboerdery te wees nie.

In Etosha word hierdie problematiek veel sterker en vollediger uitgebou. Die laaste verteenwoordigers van die ou bedeling in die Etosha Nasionale Park word uit die weg geruim: enkele wit beamptes, veldwagters en navorsers, en selfs ' $n$ groep swart soldate uit die vorige regering se Koevoetmagte en 32-bataljon wat deur die parkhoof gewerf is om wilddiefstal te bekamp. Die bestuur van die park word in die naam van regstellende aksie ondermyn en die nuwe regering begin om op groot skaal wild te oes. Ivoor word uitgevoer en leeus word gevang om in Suid-Afrika gejag te word. Dempers (2010) som die kwessie waarmee die leser gekonfronteer word, soos volg op:

5.Meyer (2017) motiveer waarom Die Sideboard se postkoloniale konteks as agter (2017) motiveer waarom Die Sideboard se postkoloniale konteks as agtergrond vir haar navorsing gebruk word. Haar studie fokus op diewyse waarop daar in Bruinders se roman met die mens se dominerende beskouing ten opsigte van natuuraspekte weggedoen word soos wat ook in die romanagtergrond op politieke en sosiale vlakke daarteen geprotesteer word. Gelees teen die agtergrond van die magsbeheer oor mense soos die hooffiguur dit in die romanhede van 1939 beleef, kry die verbreking van die patroon van oorheersing oor die plantewêreld in Die sideboard, waarop die soeklig tydens Meyer se ondersoek val, besondere betekenis.

6.In Van Rooyen se mees onlangse romans, Rodriquez (2012) en Amatola (2016), word van hierdie tematiese lyn weggebreek. Eersgenoemde is ' $n$ spioenasieverhaal, gebou rondom die wedervarings van Skerf Malan, alias Rodriques, wat in 1990 in opdrag van Naionale Intelligensie die Renamobeweging in Mosambiek moet opdrag van Naionale Intelligensie die Renamobeweging in Mosambiek moet infiltreer. Amatola is' $n$ moderne spanningsverhaal wat weer die wêreld van die San, of Boesmans betrek - dit wat in Die spoorsnyer, Gif en Agter' $n$ eland aan uitgebeeld is, maar wel op ' $n$ nuwe wyse. In Amatola gaan ' $n$ groep argeoloe van ' $n$ SuidAfrikaanse universiteit na San-rotstekening soek in die Sneeuberge in die Oos-Kaap, maar' $n$ nagmerrie tref hulle wanneer die groep deur' $h$ bende - die Amatola-oorva en aangehou word. Die span argeoloë word'n groepie wat, soos die Boesmans van ouds, in die veld moet oorleef. 
Aan wie behoort Afrika? Afrika se mense volg 'n pad van vernietiging, van sy hulpbronne, maar ook van mekaar. Eers het die wit man Afrika gestroop. Nou vat Afrikane terug wat hulle s'n is. Of dit deur korrupsie of die afmaai van diere vir hul ivoortande of horings is, dis 'n genadelose wêreld waar elkeen veg vir eie belang en gewin. [...] Fechter sien, op 'n manier wat herinner aan Joseph Conrad se Heart of Darkness, hoe die (Westerse) beskawing voor hom verdwyn, maar hy staan onmagtig en ontmagtig voor die aanslag. (p. 7)

Etosha is 'n navorsingswaardige voorbeeld van omgewingsgerigte Afrikaanse skryfpraktyk waar die impak van koloniale sisteme op die plaaslike mense ook verreken word. Die dilemmas wat uit bewaringspogings van bedreigde dierelewe spruit, word uitgebeeld met fyn aandag aan situasies waar die lewensbestaan van plaaslike mense daardeur in gevaar gestel word.

Die roman herinner die leser aan die misdaadriller Blood safari (2009) uit die pen van Deon Meyer. Hierin word die leser met 'n ekologiese krisis in die Kruger Nasionale Park gekonfronteer, ${ }^{7}$ met grondeise van die Sibashwa-stam teen die park en met die betrokkenheid van nasionale en internasionale eiendomsontwikkelingsmaatskappye, oorwegend in blanke besit, wat die armoede van die grondeisers uitbuit. Laasgenoemde word as die grootste oortreders teen die natuur uitgebeeld. Naidu (2014) betrek Blood safari in haar bespreking van Suid-Afrikaanse natuurgeoriënteerde misdaadromans, oftewel misdaadromans met 'ekososiale temas' waarin daar spanning uitgebeeld word tussen bewaringsgesindes en inheemse mense wat op grondregte aandring. Naidu (2014:60) bevind dat dit egter die konvensies van die misdaadroman is, eerder as die teenwoordigheid van omgewingskwessies, wat hierdie soort romans se aard bepaal: 'They are anthropocentric narratives [...] and specific environmental issues or crimes against nature inform the plots and themes without necessarily becoming focal elements of the narratives'. 8

'n Veel duideliker ekosentriese gesprek, met dominante postkoloniale aksente, word in Etosha aangetref. In hierdie studie word die situasie van verskillende karakters en groepe eertydse bewoners van die Etosha Nasionale Park ten opsigte van mekaar en ten opsigte van die uitgebeelde werklikheid van koloniale uitbuiting en omgewingsbenutting

\footnotetext{
7.Die krisis wat die verhaalgebeure rig, is dat daar saam met die liggame van vie vermoorde wilddiewe die oorblyfsels van 14 beskermde en bedreigde aasvoëls vermoorde wild 'iewe die oorblyfsels van 14 beskermde en bedreigde aasvoels aangetref word.' $n$ Jng vrou wie se broer in die park verdwyn het en wat ontdek dat sy aandadigheid in diemoorde geimpliseer word, huur'n speurder en dit lei tot die ontdekking van 'n twis tussen die plaaslike stam, die Sibashwa, wat groot grondeise teen die park ingestel het, en 'n groep natuurbewaarders by die rehabilitasiesentrum vir diere en voëls.

8.Naidu (2014:66) motiveer ook verder dat daar uit die saambind van sosiale, politieke en ekokritiese temalyne in Blood safari nie werklik'n ekokritiese gesprek groei nie. Individuele oortredings, sosiale euwels en onreg teenoor die omgewing word onde die groot banier van 'misdaad' uitgebeeld; die fokus is op menslike interaksie tussen die misdaadondersoeker en die misdadigers. Die impak van kolonialisme op die omgewing en op inheemse mense, asook die sosiale en omgewingsgevolge van apartheid word as onderling skakelende oorsake vir misdaad aangebied. (Naidu 2014:60 69). Meyer se held die speurder Lemmer, verteenwoordig waarheid en 2014:60, 69). Meyer se held, die speurder Lemmer, verteenwoordig waarheid en geregtigheid in ' $n$ algemene sin en is aan geen omgewingsaak of -stryd gekoppel nie. Naidu (2014:66) meen daarom dat hier selfs sprake is van ' $n$ slim tegniek om die kwessie van omgewingsverantwoordelikheid in die roman te systap. Haa gevolgtrekking is dat natuurgeorienteerde misdaadromans wel die aandag op misdade teen die natuur vestig, maar dat it has to be acknowledged that ecological topics are exploited to fulfill generic conventions or end up playing second fiddle to them' (Naidu:69)
}

en -verwoesting verken. Die doel is om vas te stel hoe genuanseerd en oortuigend hierdie rolspelers se werklikhede voorgestel word ten opsigte van die konteks wat gebied word. Verder word ondersoek ingestel na die besonderhede omtrent elke rolspeler se standpunt en situasie, en hoe dit bydra tot die uitbeelding van die kompleksiteit van die bewaring-benuttingkwessie in die postkoloniale konteks bydra. Die aandag is toegespits op die wyse waarop en die mate waartoe die teks die leser met die vraag konfronteer wat op die roman se voorblad gestel word: 'Wie is werklik reg, wat is geregverdig in die stryd om oorlewing?'

Die kernaspek van hierdie ondersoek is die integrasie van die insigte wat die postkoloniale studies en die ekokritiek in die ontrafeling van die vraagstukke in Etosha bied. Die studie word gerig deur die uitdaging om 'n wesenlike bydrae tot die ontwikkeling van 'n Suid-Afrikaanse ekokritiek te lewer, spesifiek in die veld van die Afrikaanse verhaalkuns. Verder word gepoog om 'n antwoord te help vind op die vraag wat die Suid-Afrikaanse ekokritiek, teen die agtergrond van die land se geskiedenis, van dié in die internasionale arena onderskei. Die invalshoek vir die bestudering van Van Rooyen is dus gekies met die doel om vas te stel hoe ekokritiek en postkoloniale kritiek meewerk daartoe om, soos Smith (2013) dit stel, Afrikagerigte vrae te vra wat Afrikagerigte, plekspesifieke antwoorde tot gevolg kan hê.

Eers moet die konsepte postkolonialisme en die ekokritiek teoreties verantwoord word binne die raamwerk van die konflikte en die dialoog wat tussen hulle bestaan.

\section{Postkoloniale studies en die ekokritiek: Die konflikte en die dialoog}

Postkoloniale kritiek behels die kritiese diskoers rondom kwessies wat uit koloniale verhoudings en die nasleep daarvan te voorskyn kom. Ashcroft, Griffiths en Tiffin (1989:2) beklemtoon dat die postkoloniale wyses van skryf en teoretiseer die koloniale maniere van dink en doen wil verplaas, maar ook dialekties daaraan vassit. Postkolonialisme hou dus sowel die ondermyning as die noodwendige voortsetting van kolonialisme in. Huggan en Tiffin (2007:3) wys op die parallel tussen die ontginning of uitbuiting van hulpbronne in voorheen gekoloniseerde lande en die 'gewelddadige koöptasie' van mense in postonafhanklikheidslande by westerse regeringstelsels en wêreldbeskouings wat onder hedendaagse globaliseringsprosesse voortgaan. Uitbuiting deur multinasionale maatskappye, dikwels in vennootskap met korrupte postonafhanklikheidspolitici, bring mee dat die armer meerderheid van mense in hierdie lande dikwels hulle tradisionele bestaansvorms ontsê word, terwyl hulle steeds ook toegang tot die winste van hulle eie hulpbronne geweier word (Huggan \& Tiffin 2007:2).

Met die skep van nasionale parke en die beskerming van bedreigde spesies word inheemse mense weggewys uit die 
gebiede wat hulle vir eeue bewoon en bewerk het. Hulle word belemmer in die benutting van natuurlike hulpbronne as 'n ekonomiese basis in die strewe na 'n meer moderne bestaan (Huggan \& Tiffin 2007:3). Die konflik tussen hedendaagse bewaringsdoelwitte en die regte van die plaaslike inheemse mense, wat die kern van die situasie van die Etosha-bewoners in Van Rooyen se roman vorm, is relevant vir sowel postkoloniale as omgewingsgerigte studies.

Die etiese dimensie wat deur die vrae op die voorblad van Etosha geaktiveer word' is 'n belangrike komponent van die ekokritiek. Buell (1995:11) definieer ekokritiek as die bestudering van die verhouding tussen letterkunde en die omgewing wat in 'n gesindheid van toewyding aan omgewingskundige praktyke of -gebruike onderneem word. Buell, Heise en Thornber (2011) omskryf die ekokritiek in vollediger terme, maar met dieselfde aandag aan die etiese element daarin:

Ecocriticism is a cross-disciplinary initiative that aims to explore the environmental dimensions of literature and other creative media in a spirit of environmental concern not limited to any one method or commitment. Ecocriticism begins from the conviction that the arts of imagination and the study thereof - by virtue of their grasp of the power of word, story, and image to reinforce, enliven, and direct environmental concern - can contribute significantly to the understanding of environmental problems [...]. In this, ecocriticism concurs with other branches of the environmental humanities - ethics, history, religious studies, anthropology, humanistic geography - in holding that environmental phenomena must be comprehended, and that today's burgeoning array of environmental concerns must be addressed qualitatively as well as quantitatively. (p. 418)

Wanneer Vital (2008:87) ten gunste van die ontwikkeling van 'n ekokritiek binne die konteks van Suid(er)-Afrika argumenteer, stel hy 'n gekombineerde poging uit die velde van die ekokritiek en postkoloniale studies voor. Wat met so 'n poging in berekening gebring moet word, redeneer Vital (2008:90), is 'the complex interplay of social history with the natural world, and how language both shapes and reveals such interactions'. Daar is egter ' $n$ mate van filosofiese antagonisme tussen hierdie studievelde. In Rob Nixton se baanbrekerswerk Environmentalism and postcolonialism (2005) sit hy belangrike verskille tussen die benaderings van die twee dissiplines uiteen, aspekte waarna Buell et al. (2011:421) ook verwys. Postkolonialisme plaas die aspekte van kruiskulturaliteit, hibridisering en kreolisering op die voorgrond, binne die konteks van historiese prosesse; binne die ekokritiek word die suiwerheid van ruimtes en ekosisteme beklemtoon. Postkoloniale studies is geïnteresseerd in diaspora en ontworteling of ontheemding, terwyl ekokritici bande met plek en 'n ervaring van in plek te behoort, belangrik ag. Binne 'n postkoloniale raamwerk word die aandag op die kosmopolitiese en op transnasionale verbindings gevestig; die fokus van die ekokritiek is lokaal en nasionaal. Laastens wend postkoloniale kritici hulle tot die verlede in pogings om die geïgnoreerde geskiedenisse van ondergeskiktes te 9.Na hierdie vrae is reeds verwys: "Wie is werklik reg, wat is geregverdig in die stryd om oorlewing?'. herwin of terug te eis, terwyl ekokritici hulle tot natuurbelewing en -bestudering buite menslike narratiewe van tyd wend (ibid:421-422). Huggan (2004) beskou laasgenoemde verskil as die ingrypendste:

Deep ecologists might argue that postcolonial criticism has been, and remains, resolutely human-centered (anthropocentric); committed first and foremost to the struggle for social justice; postcolonial critics have been insufficiently attuned to life-centered (eco- or biocentric) issues and concerns. (p. 702 $)^{10}$

Perspektiefverskille tussen hierdie dissiplines desondanks, wys Roos en Hunt (2010:5) op toenemende - en uitstekende vakkundige pogings om dialoog tussen die ekokritiek en postkolonialisme tot stand te bring. Hulle wys op die rol wat Deane Curtin se boek Environmental etics for a postcolonial world (2005) en dié van Robert P. Marzec, An ecological and postcolonial study of literature: From Daniel Defoe to Salman Rushdie (2007), in hierdie verband gespeel het. Curtin (2005:ix) fokus op etiese aspekte as die interdissiplinêre kruispunt tussen die dissiplines en op 'n etiese invalshoek om snypunte in die wyses waarop sosiale en omgewingskwessies bedink word, te skep. Marzec (2007:2) dink in dieselfde rigting; hy redeneer dat die koloniale drang na privatisering en pogings om landboutegnologie na ongerepte grondgebiede te bring, daartoe lei dat grond en die natuur onder kategoriese en ekonomiese beheer gebring word - 'n proses wat tans in verskillende gedaantes voortgesit word. 'To realize such a history deeply encoded in a Western literary tradition is one path to reawaken an ontological understanding of land' (Marzec 2007:2). Huggan (2004) het reeds vroeër daarop gewys dat kulturele kodes deel is van die morele debatte oor grondgebruik, bioetiek en die regte van inheemse mense:

Cross-cultural understanding is needed as much as an ability to decide what is right or wrong in any given event. What makes sense as a preservation strategy in the first world often has disastrous consequences in the third world. (p. 702)

Uit die denke van Huggan, Curtin en Marzec kom die gedeelde idee van nuwe, omgewingsgeörienteerde kritiek (green critique) ten opsigte van koloniale en postkoloniale tekste om die weg tot etiese omgewingspolitiek te baan, wat in ooreenstemming met universele besorgdhede oor geregtigheid is.

Nog stemme wat duidelik in hierdie gesprek opklink, is dié van Cilano en DeLoughrey. Hulle erken eerstens die spanning wat tussen die velde van postkoloniale studies en die ekokritiek bestaan en verwys na Nixon se netjiese uitleg van die benaderingsverskille tussen hierdie studieterreine, wat reeds hierbo gemeld is (Cilano \& DeLoughrey 2007:79-80). Hulle fokus egter op twee belangrike en gemeenskaplike

10. Die digotomie van antroposentrisme versus biosentrisme staan sentraal in die denkskool van die Diep Ekologie. Porritt (1984) beskryf die uitgangspunte daarvan soos volg:

The belief that we are 'apart from' the rest of creation is an intrinsic feature of the dominant world-order, a man-centered or anthropocentric philosophy. [...] This ultimately destructive belief must be rooted out and replaced with a life-centered or biocentric philosophy. (p. 206)

Aanhangers van die 'diep-ekologie-' of die 'donkergroen'-denkbeweging, verkies gewoonlik om hulle van die 'liggroen' beweging te onderskei, aangesien laasgenoemde minder radikaal in denke is en hulle hoofsaaklik op die bestuur van omgewingsprobleme toespits (Dobson 1990:13). 
doelwitte wat hierdie dissiplines tot gespreksgenote in 'n samehangende dialoog saambind. Eerstens deel postkoloniale en ekokritiese studies die verbintenis tot ' $n$ interdissiplinêre werkwyse en benut albei insigte uit die sosiale sowel as die omgewingswetenskappe (ibid:73). Die tweede parallel tussen die dissiplines is dié wat Curtin en Huggan reeds as betekenisvol uitgelig het, naamlik toewyding aan die kwessie van sosiale en omgewingsgeregtigheid. Cilano en DeLoughrey (2007) ondersteun die standpunt van die ekokritikus Patrick D. Murphy:

Ecocriticism's concern for nonhuman nature mirrors postcolonial, feminist and multicultural studies in so far as the latter three are 'focused on extending equitable moral considerability and social justice to excluded, exploited, and oppressed peoples'. (p. 75)

Buell (2005:97) laat hom oor hierdie saak uit met verwysing na die ooreenkomste in die ideologiese uitgangspunte van postkoloniale studies en die ekokritiek; hy vind dat 'n saamvloei na 'n ontmoetingspunt moontlik en goed motiveerbaar is. Postkoloniale kritiek op Europese imperialisme en kolonialisme is uit die staanspoor gevoed deur kommer oor kwessies op etiese en politieke vlakke; die beoefening van ekokritiek het tot 'n groot mate gegroei uit die verontrusting oor die welstand van ons planeet en sy bewoners (ibid:97). Sheng-Yen (2010:85) sien 'n betekenisvolle oorvleueling in die praktiese ingesteldheid van die dissiplines. Hy verwys na die beskouing van ekokritiek in die voorwoord van Harrington en Tallmadge se Reading under the sign of nature: 'Ecocriticism is really less a method than an attitude, an angle of vision, and a mode of critique'. Sheng-Yen (2010:85) beskryf postkolonialisme dan op dieselfde wyse: dit is in beginsel ook ' $n$ ingesteldheid, ' $n$ bepaalde perspektief en 'n wyse van kritieklewering.

Roos en Hunt (2010:3) gebruik die term globalisering in die gesprek oor die saamvloei van die velde van die postkoloniale en ekokritiese studies. Hulle verstaan globalisering as 'n hedendaagse kolonialisme gebaseer op ekonomiese en kulturele imperialisme; die uitdagings daarvan kan dus die beste op die gebied van die postkoloniale teorie hanteer word. Die kwessies van grond en natuurlike hulpbronne is egter direk betrokke; globalisering behels ook aktiwiteit op die gebiede van industrie en ontginning met groot ekologiese en omgewingsimpakte. Roos en Hunt (2010:3) beklemtoon dus dat 'any postcolonial critique must be thoroughly ecocritical at the same time'. Hulle gebruik dieselfde term as Huggan en Tiffin (2007), naamlik groen postkolonialisme (green postcolonialism), om na die bondgenootskap tussen hierdie studievelde te verwys, met die doel om teen voortgaande imperialistiese en oorheersende gebruike op sosiale en omgewingsvlakke te protesteer en om tot beter insig ten opsigte van sekere kwessies en verskynsels te kom. Cilano en DeLoughrey (2007) noem dit postkoloniale ekokritiek. Met albei terme word erkenning aan die volgende verleen: 'Our world is locked is a dance of cultural, economic, and ecological interdependence. This interdependence calls for a multiplicity of voices to address the problems that our world faces today' (Roos \& Hunt 2010:3).
Wanneer die opinies van al bogenoemde teoretici in aanmerking geneem word, lyk dit asof die kernkonsep wat ruimte skep vir teoretisering in 'n gees van samewerking tussen die ekokritiek en postkoloniale studies, dié is van geregtigheid. Vir Huggan en Tiffin (2007:10) behels dit die ommekeer van die nalatenskap van Eurosentriese ideologie waarin kolonisering en oorheersing van die etniese ander onafskeidbaar met die 'verowering' of 'onderwerping' van die natuur verstrengel is. Huggan en Tiffin (2007:10) sien die ideaal ten opsigte van hierdie situasie soos volg: 'No social justice without environmental justice; and without social justice - for all ecological beings - no justice at all'. Met formulerings soos dié is dit sekerlik ook nodig om op Cilano en DeLoughrey (2007:75) se waarskuwing ag te slaan dat daar in die rigting beweeg kan word van 'n denkingesteldheid waarvolgens skeiding tussen die mens (aan die postkoloniale kant) en die niemenslike (aan die ekokritiese kant) voorgestel word. Die term omgewingsgeregtigheid is egter betekenisvol. Dit dui juis op die volledige vereenselwiging van twee sake: dié van die omgewing, wat prominent in die term vasgevang is, en dié van die mens wat as deel van daardie omgewing beskou word. Buell et al. (2011:419) omskryf omgewingsgeregtigheid as aksies of maatreëls met die doel om die ongelyke verdeling van omgewingsvoordele en risiko's tussen bevolkingsgroepe teen te staan. Roos en Hunt (2010:3) beskou omgewingsgeregtigheid as die lens waardeur ekokritici duideliker kan sien hoe ontwortelde en verarmde mense regoor die wêreld omgewingsbewaringskwessies interpreteer. Aangesien geregtigheid in die postkoloniale diskoers aan die kwessie van seggenskap oor mense gekoppel word, asook aan die vermoë om 'n selfonderhoudende, onafhanklike leefwyse te kan handhaaf, is 'n belangrike saak dié van ekonomiese druk wat op mense geplaas word wanneer onteiende grond as 'beskermde' gebiede en wildparke verklaar word. Roos en Hunt (2010:3) argumenteer dat omgewingsgeregtigheid ekokritici met die totaliteit van die moontlike implikasies van 'n bewaringsingestelde denkwyse konfronteer en met verskillende uitdagings ten opsigte van groter bewustheid van en sensitiwiteit vir rasse- en kulturele kwessies. Vir die bestudering van Etosha en my spesifieke invalshoek ten opsigte daarvan, is die kwessie van omgewingsgeregtigheid direk relevant.

Die term wat ek verkies om na die metodologiese raamwerk te verwys met behulp waarvan die belange van die mens langs dié van die natuur ingeskuif word, en wat aan skrywers en teoretici toerusting verskaf om op voortgaande politieke en omgewingsprobleme te reageer, is groen postkolonialisme. Ek beskou dit, soos Heise (2010), as 'n 'produktiewe oorvleueling' tussen die werkwyses waarin sosiale geregtigheid en omgewingsbesorgdheid onderskeidelik sentraal staan; vanuit verskillende denkraamwerke word na die beste moontlike konseptualiseringswyse gestreef ten opsigte van die hede sowel as die verlede, van die menslike sowel as die niemenslike, op maniere wat oorgeërfde vorms van dominansie ondermyn. 
Increasingly, ecocritics have come to emphasize that environmental problems cannot be solved without addressing issues of wealth and poverty, over-consumption, underdevelopment, and resource scarcity, while postcolonial critics have highlighted the ways in which historical struggles over colonial power structures as well as contemporary conflicts over economic globalization have involved and continue to revolve around fundamental environmental questions of, for example, land ownership, energy needs and uses of natural resources. (p. 252)

In die volgende afdeling word Etosha bestudeer met aandag aan die uitbeelding van die denkraamwerke van die verskillende karakters en groepe van waaruit bewaringsgebiede en -pogings geïnterpreteer word. Die doel is om die konteks en besonderhede van hierdie karakters en groepe se standpunte en situasies vas te stel, om sodoende te bepaal op watter wyse(s) en in watter mate die roman tot die gesprek oor die kompleksiteit van die bewaringbenuttingkwessie in die postkoloniale konteks bydra. Die ondersoek word dus gebou rondom die vraag op watter wyse groen postkolonialisme in Etosha beslag kry; hoe bewaringsgerigte en postkoloniale perspektiewe in hierdie roman saamvloei om van die roman 'n betekenisvolle werk binne konteks van die ontwikkeling van ekokritiek in SuidAfrika te maak. Die ondersoek is gerig op die wyse waarop die roman die leser uitdaag om die volle kompleksiteit van die vraag, 'Wie is werklik reg, wat is geregverdig in die stryd om oorlewing?', binne die plaaslike konteks te probeer begryp; hoe die roman die leser dus konfronteer met die noodsaak om tot 'Afrikagerigte, plekspesifieke antwoorde' te kom op dit wat Smith (2013) 'Afrikagerigte vrae' noem.

\section{Groen postkolonialisme in Etosha}

Teen die muur van die Etosha Ekologiese Navorsingsinstituut waar die veearts Olivia gestasioneer is, hang kaarte wat die aard en die gebied van haar navorsing aandui:

Dit sluit die Nasionale Etosha Wildtuin, 'n gedeelte van die Opuwo-kommunale gebied en die boerderydistrikte van Outjo, Grootfontein en Tsumeb in. [...] Hier en daar is rooi vlaggies met kodenommers ingesteek waar die leeus op plase doodgeskiet is, groen vlaggies op die plekke waar sy betyds kon kom om die verdowingspyle te gebruik en van waar sy die leeus kon terugvat Park toe. Geel vlaggies binne die park dui die verskillende gebiede aan waar sy verdoofde leeus vrygelaat het met hul nuwe identifikasie-halsbande aan. [...] Dikwels eindig 'n kode met ' $n$ rooi vlag. (pp. 46-47)

Die gebeurelyn in Etosha is rondom die dilemmas gebou wat ontstaan wanneer die bewaring van bedreigde diere, wat Karel Fechter se lewensmissie is, die lewensbestaan van plaaslike mense in gedrang bring. Die roman betrek die situasies van die Himbas en die Heikum - groepe wat hulle reg op die gebied verloor het met die proklamering daarvan as 'n nasionale park en wat elders hervestig is. Met die uitbeelding van hierdie groepe se situasies in die visier, word die navorser egter dadelik met 'n probleem gekonfronteer. Die postkoloniale bemoeienis met die ondergeskiktes van die
Suid(er)-Afrikaanse geskiedenis, die stemlose groepe of sogenaamde subalterns wat deur Ashcroft, Griffiths en Tiffin (2007:198) omskryf word as 'groups in society who are subject to the hegemony of the ruling classes', stel die wit Suid-Afrikaanse skrywer voor 'n uitdaging. Viljoen (2002:92) waarsku teen die gevaar dat die skrywer, in sy poging om stem aan die onderdruktes te gee, sal voorgee dat hy 'homself in die proses volkome deursigtig kan maak en dat hy die "ware" stem van die stemlose kan weergee'. Nog 'n gevaar, meen Viljoen (2002:92), is dat die praat oor of namens die stemlose gesien sou kon word 'as 'n verdere poging om koloniale outoriteit oor die onderdruktes uit te oefen deurdat hulle stemme geapproprieer word vir die persoonlike doeleindes en gewin van die outeur'.

Met hierdie waarskuwings in gedagte, is my ondersoek gekwalifiseerd. Dit is nie daarop gerig om die uitbeelding van die belewings van die verskillende groepe (of individue in daardie groepe) te analiseer met die doel om enige beoordeling te kan waag oor die geldigheid, geloofwaardigheid, geslaagdheid of etiese oorwegings ten opsigte van die pogings van die implisiete outeur om in die skoene van die subaltern te kan staan en aan hulle persoonlike ervarings gestalte of 'stem' te kan gee nie. Ek ondersoek slegs die uitbeelding van die situasies van die groepe in die Etosha Nasionale Park, asook die kwessies voortspruitend uit die situasie waarin elkeen homself bevind. Op hierdie wyse bly die aandag toegespits op die wyse waarop die roman poog om twee wêrelde byeen te bring: besorgdheid oor mense en oor niemenslike lewe. Vervolgens word die situasies van die Himbas, die Heikum en ook dié van die hooffiguur, die parkhoof Karel Fechter, ondersoek.

Justus is die seun wie se toekoms op die spel is wanneer sy pa vroeg in die roman op die vlug is. Etosha se teenwilddiefstaleenheid is op die vlugtende se spoor; die renosterhoring wat hy uiteindelik moet laat los, moes aan sy slim seun Ndjipua (Justus) 'die lewenskans gee, om hom iets te laat word' (p. 33). Die beoogde universiteitskwalifikasie sou ook Justus se mense kon help, 'hulle uit die Bos uit haal' (p. 35). Justus was bewus van sy pa se jagtogte die park in en van die standpunt: 'Dit was nog altyd ons plek, hierdie wêreld, hoekom sal ons nou uit ons eie jagveld afgekeer word?' (p. 64). In sy pa se jongdae, weet hy, was die park deel van hulle stam se leefwêreld, maar dis 'afgekamp' voor hy gebore is om 'die wit man se land' te raak (p. 82). Dat die grond egter steeds as onvervreembare eiendom van die Himbas beskou behoort te word, word deur die ozonganga (toordokter) beklemtoon tydens Justus se besoek om 'pad te vra' ná sy pa se dood. Hierdie grond is nie deur gevegte of ooreenkomste met ander groepe bekom nie, verduidelik die ozonganga.

Al hulle (die Tjambiro-stam) se regte op die grond is deur die ou rituele praktyke vasgemaak wat die wetlikheid van hulle aansprake oor en oor bevestig het. Die rituele praktyke van die voorvaders [...] het hierdie land hulle s'n, ons s'n, gemaak. (p. 81)

Justus ag dit sy plig om sy pa se moordenaar op te spoor, en pak die laaste deel van hierdie soektog aan wanneer hy jare 
later, in diens van Nasionale Intelligensie, die opdrag kry om 'n ontsnapte gevangene aan te keer: Karel Fechter, onder wie se beheer die APU's in Etosha gefunksioneer het.

Die Heikum word deel van die gebeure in Etosha wanneer 'n boodskapper Fechter se kantoor binnestorm met nuus: 'n Groep van meer as honderd Heikum blokkeer die Andersonhek na die park en weier deurgang aan toeriste, terwyl 'n kleiner groep voor die Namutoni, 'n Duitse fort uit die vervloë koloniale tye, saamdrom. Fechter som die groep se griewe iewat ongeëerg teenoor 'n kollega op as 'die kwessie van die voorvaderlike grond, ou jagplekke' (p. 114). Hy stuur die APU's, 'n geharde groep wat hy saamgestel het uit 'die eertydse vyand, Koevoete en uitgeweke Angolese soldate' (p. 121), om die probleem by die hek uit te sorteer. In 'n gesprek met Mentoor, die skakelpersoon wat die Heikum gebruik om oor hulle regte te praat, word Karel herinner: 'Dit was [...] hulle park in die eerste plek' (p. 122). Hy swaai die gesprek egter sonder erg weg in die rigting van die ECC, 'n drukgroep vir regstellende aksie in die park vir wie Mentoor ook as spreekbuis optree. Ondanks die groep se naam, die Environmental Concerns Committee, glo Karel dat hulle nie werklik oor die omgewing bekommerd is nie, maar 'die rassekitaar slaan'. Hy weet dat die ECC vir hom en die APU's in hulle visier het, aangesien laasgenoemde 'blote askari's vir die wit mense' is en 'te lank vir die verkeerde army geveg het' $^{\prime}$ p. 127).

Kort hierna word Karel weer met die situasie van die Heikum gekonfronteer wanneer hy hulle hulp as spoorsnyers nodig het, om te probeer vasstel wie vir die verwoestende brande verantwoordelik kon wees. Hy laai 'n groepie Heikum op by 'n wildplaas aangrensend aan die park, waar die Belgiese eienaars aan hulle verblyf gegee het - 'n gebaar van maatskaplike verantwoordelikheid nadat die bom destyds in die buitelandse pers gebars het: 'Apartheidstaat skop Boesmans uit hulle voorvaderlike gronde' (p. 199). Met die inry by Anderson se hek herinner Langman (Albert Aib) hom: 'Ja, hier't julle mos laas soos ongediertes op ons laat

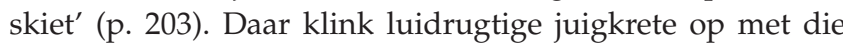
aankoms by Okaukuejo, en Karel kan hierdie uitbundigheid begryp:

Hulle is soveel jare gelede hier weggejaag om plek te maak vir die diere en die toeriste, dat dit nou soos 'n tuiskoms voel. Die Boesmans voel steeds dat hulle die reg het op die plek, dat dit hulle voorvadergronde is, dat hulle eendag sal terugkom om op te eis wat hulle s'n was. (p. 203) $)^{11}$

11.Hier word na die verwydering verwys van die Heikum San, geslagtelange bewoners van die gebied wat in 1954 die Etosha Nasionale Park geword het (Cupido 2015) Die meeste van hulle het as arbeiders op plase aanliggend aan die park beland. Met die onafhanklikheidswording van Namibië in 1990 het die nuwe Namibiese regering moderne bewaringstrategieë voortgesit, geskoei op die beginsel dat beskerming van die natuurlewe die uitsluiting van mense uit beskermde gebied behels - ook van die inheemse groepe wat rentmeesterskap oor die hulpbronne in daardie gebiede uitoefen, in ritme met die plant- en dierelewe van die streek. Cupido (2015) verwys na hernude pogings van die verarmde Heikum-mense in 2015 , om die uitsetting van die laaste oorblywendes van hulle stam uit die park in die , om die uitsetting van die laaste oorblywendes die hof te probeer teenstaan. Die Legal Assistance van Namibië is genader om die hof om erkenning te vra vir die feit dat hierdie gebied histories in die Heikum se besit was, deur hulle bestuur is ooreenkomstig hulle kultuur en gebruike en dat dit, volgens inheemse wetsbeskouings, op eienaarskap neerkom wat nooit eksplisiet beëindig is nie. Die groep het in 2015 weereens aangedring dat die Namibiese regering hulle toelaat om voordeel te benut uit die park, asook dat die reste van hulle kultuur gerespekteer sal word (ibid).
Die behoeftes van die plaaslike mense word direk teenoor Karel se ideaal van 'n ongeskonde wildernis geplaas met sy besoek aan Hoofkantoor. Hy moet hoor:

Die president en die ander ministeries sien wildbewaring nie as prioriteit nie. Daar is baie ander en dringender dinge op die sakelys. Toerisme is 'n luukse, ons parke net 'n speelplek vir die buitelanders. (p. 118)

In die gesprek met Mentoor, net ná die insident by die parkhek, word die konflik van belange in dieselfde duidelike terme uitgespel:

Ek voel niks vir die wilde diere nie. Wat my betref, kan die armes hulle almal opvreet. Hulle het die vleis nodig. Ek weet wel dat toerisme ' $n$ goeie verdiener van geld is. En dat ons toerisme nodig het, moet verduur ter wille van die toekoms van hierdie nuwe, onafhanklike land van ons. (p. 125)

Karel se situasie is een van verdeeldheid. Aan die een kant is hy trots daarop dat die park so lank staande kon bly teen die aanslae van wilddiewe, 'al daardie hongeres, die armes daar buite' (p. 227); hy verklaar teenoor minister Koos Badenhorst: 'Natuurbewaring is my lewe. [...] Ek staan of val daarby' (p. 224). Sy beroeps- en lewenstaak stem ooreen, hy wil die diere 'tot elke prys' beskerm (p. 222). Daarom word sy bestaan omgekeer deur die wending met die ontbinding van sy teenwildiefstaleenheid en met die vragmotors vol ivoor wat die park inkom, vermoedelik uit Angola, om in store geberg te word. Hy probeer ongelowig en desperaat om hierdie skuiwe te interpreteer:

Beteken dit dat die regering nou natuurbewaring opgee? Dink hulle dat hulle meer uit ivoor gaan verdien as uit hekgeld? Die hele Damaraland se renosters, Boesmanland se olifante, die Caprivi se swartwitpense, die lechwes - is die jag nou oop vir almal? (p. 217)

Bykomend by die feit dat Karel die gegewe van hierdie 'amptelike uitmoordery' (p. 224) moet verwerk, word hy ook met die negatiewe impak van globalisasie gekonfronteer. In die omusati-bos oos van Tsandi hou 'n troppie olifante, hoofsaaklik koeie en jong diere, wat - volgens Karel se oordeel - 'nog nooit iemand gepla het nie' (p. 187). Hierdie diere word skielik deur ingrepe van buite bedreig, waarin koloniale praktyke deurskemer. Karel som die kern van die krisis op teenoor Olivia:

Nou het die regering skielik nuwe boorgate gaan sink in die afgeleë gedeeltes. Die mense het glo gekla hulle weiding raak op by Omugulu-gwombashe. Geld gekry van donateurs, die Swede of die Nore, dink ek, sementdamme gaan oprig met krippe en pype. Nou kla die hoofman die olifante breek die installasies, hulle beeste kry glo nie water nie, daar was al vrektes. Ons moet die hele trop gaan uitskiet. (p. 187)

In hierdie gegewe is die effek van 'n 'kleiner geworde aarde' weens globale verbintenisse goed herkenbaar; 'n saak wat volgens Roos en Hunt (2010:2) onder andere verband hou met internasionale handelsverhoudings en internasionale kapitaal vir 'ontwikkelende nasies'. Roos en Hunt (2010:2) oordeel dat veel verander het, maar dat veel ook bekend vertoon: Waar imperiale magte Afrika en Suidoos-Asië 
vroeër vir koloniale gewin verdeel het, kom hedendaagse Westerse magte tot die ekonomiese en humanitêre 'redding' van 'ontwikkelende' groepe by wyse van opheffings- en ontwikkelingsprojekte. Huggan en Tiffin (2010) verduidelik dat postkoloniale ekokritiek Westerse ideologieë van ontwikkeling teenstaan sonder om noodwendig die idee van ontwikkeling self te verwerp:

The battle is not so much against development itself as an intrinsically harmful activity or process as against the flagrant social and environmental abuses that continue to be perpetrated in its name. (p. 19)

In Etosha word sulke omgewingsmisdrywe gedemonstreer. Karel betoog: 'Die olifante was eerste daar. Voor die mense. Hulle het hulle nog altyd stil gehou, goed gedra. Nou het hulle skielik kamtig probleemdiere geword' (p. 187).

Uiteindelik sien Karel sy situasie as natuurbewaarder binne die groter prentjie wat aan hom opgedring word deur die problematiek van globalisasie:

Hy besef dat niks die diere meer kan red nie. Daar is te veel smokkelaars, te veel rebellies, te veel oorloë die wêreld vol, hope gewere oraloor. Op die lughawens kom die goedere uit Nigerië en Latyns-Amerika ingestroom, saam met [...] ruime vol onwettige produkte. Skepe vol krygsmateriaal, rantsoen en oorlogswapens kom meer in die hawens vas. (p. 228)

Die een kant van Karel se situasie behels dus 'n toegewyde bewaringsingesteldheid en die vermoë om mens en dier binne konteks van die groot geskapenheid te kan plaas. 'Die olifante was eerste daar, voor die mense' (p. 187), sê hy, en: 'Ek sal hierdie plek beskerm tot my laaste druppel sweet toe. [...] Al is dit vir geen mens nie, bloot vir die onthalwe van die diere self' (p. 223). Aan die ander kant word Koos beweeg tot erkenning dat hy nooit tevore die groter prentjie van menslike verontregting en lyding kon sien nie. 'Hoe maklik was dit nie toe om mense baie jare lank tronk toe te stuur, om ' $n$ lot met ' $n$ pennestreep te bepaal, enige saak met 'n stempeldruk af te handel nie?' (p. 227). Die kant van die saak wat hy verkies het om te ignoreer, word aan hom uitgespel:

Swapo het hierdie stryd in die eerste plek baklei op grond van die steun van hulle eie mense. En die eie mense soek ander belonings. Mooi prentjies van 'n ongeskonde wildernis is 'n luukse. Die mense soek grond, geld, werk, kos en klere. Dis die materiële wat saak maak. (p. 118)

Kort nadat Karel ingelig word dat die park 'n nuwe hoof gaan kry, bereik inligting oor die 'ivoor-racket' in die Etosha Panne die Amerikaanse Times en Karel word as verdagte ten opsigte van die uitlek van hierdie inligting gearresteer. In die ivoorstoor waar hy gevange gehou word, omring '... deur opgehoopte tande soos 'n groot woud van afgekapte, vernietigde bome waarvan net die kaal, gestroopte stamme nog [...] sigbaar is' (p. 226), beleef hy 'n angsdroom. Dit oortuig hom dat die stryd 'te groot geraak het om teen wal te gooi', dat 'almal 'n deel (wil) hê van die bietjie wat nog oor is' (p. 227):
Hy hoor van ver die gedreun van die strydliedere. Dis die armes wat sing, die hongeres, die gepeupel. [...] Hulle kom in massas in die park in. Hulle slag wat voorkom, waar hulle kan. [...] Die wilddiewe kom direk voor die patrollievoertuie ingestap. Hulle skud die vuiste, die kieries, die gewere uitdagend. Hulle skree met dun, klaende stemme bokant die geluid van die masjiene uit. [...] Hulle is te veel [...] Hulle is 'n magdom, te vol [...] van die groepsgees wat hulle dra. Hulle knip die laaste drade, [...], steek die vure aan die brand. (p. 229)

Karel vind 'n beeld uit die natuur om tot begrip van die geheelsituasie te kom: 'Daar is 'n ander wet wat nou geld, die oudste wet van almal: die wet van die natuur, die wet van roofdier en prooi, dat die sterkste altyd wen' (p. 227). Daar ontstaan ook by hom 'gelatenheid' dat 'die verloop van dinge nie in jou hande lê nie', gepaardgaande met insig omtrent die mens se onbeduidende rol binne die geheel van dinge, 'dat die mens net daar is om saamgesleur te word in die wiel van tyd, die matrys van bestaan' (p. 230). Dit is insig 'waarteen die wit man so lank probeer veg, maar wat Afrika lankal reeds aanvaar het, dat die aarde draai soos hy draai'; Karel is 'deel van 'n groot bewegende stroom wat na die oneindigheid toe op pad is' (p. 230).

\section{Gevolgtrekking}

Die werklikhede van koloniale uitbuiting en omgewingsverwoesting word in Etosha genuanseerd uitgebeeld, met fyn aandag aan die besonderhede omtrent die konflik van belange en aan verskillende situasies wat realisties voorgestel word. Gesigte, name en gemotiveerde interpretasies word aan verskillende rolspelers in die komplekse geheel van die postkoloniale bewaring-benuttingscenario geheg. Die uitgangspunte van die parkhoof, vir wie bewaring 'al is wat saak maak' (p. 222), en dié van die onteiende Himba- en Heikumgroepe wat die gebied van Etosha vroeër bewoon het, word byeengebring en opgeweeg in 'n roman wat kritiese vrae oor die haalbaarheid van bewaringsdoelwitte in Afrika vra. Die kernvraag is: Aan wie behoort Afrika? Dié kontinent se mense volg die pad van vernietiging: van sy hulpbronne, maar ook van mekaar. Die boodskap in Etosha kan kortliks soos volg geformuleer word: Eers het die wit man Afrika gestroop. Nou neem inheemse mense terug wat as hulle s'n beskou word - of dit nou deur korrupsie of die afmaai van diere vir hulle ivoor of horings is. Dit is ' $n$ genadelose wêreld waar elkeen vir sy eie belang en gewin veg. Fabianus, hoof van die teendiefstaleenheid, sê: 'Hierdie land gaan homself opvreet, totdat daar niks meer oor is nie' (p. 211). Daar is 'n suggestie van: Dit is te laat, die hongeres is te veel. Die vure wat in Afrika brand, gooi "n donker rook oor alles' (p. 229). Karel sien hoe die (Westerse) beskawing, die 'bietjie Europa wat in Afrika ingedring het' (p. 227), voor hom verdwyn, maar hy staan onmagtig en ontmagtig voor die aanslag.

Die leser word nie slegs uitgedaag deur die enorme kompleksiteit van die vraag oor wat geregverdig is in die stryd om oorlewing nie, maar ook met die ongemaklike vraag: Wat is ons verantwoordelikheid nou in Afrika? Ons het bygedra tot die verwoesting van die natuur en natuurlike 
hulpbronne, is dit reg om ons nou op te hou bekommer oor die einde daarvan? Hierdie vraag impliseer 'n kritiese beskouing van die mens en die destruktiewe optrede waartoe die verskillende situasies waarin hy hom kan bevind - dié van heerskappy en dié van oorheersing - hom in staat kan stel. In Etosha word die leser uiteindelik ook gedwing om deur Karel Fechter se oë te kyk na die relatiwiteit van die mens se 'mag', na sy nietige en vervlietende plek in die groter, standhoudende stroom van natuurkragte. Die mens is "n sandgeitjie wat 'n vae sleepspoor op 'n duin laat, byna onherkenbare merke, spore wat die wind onmiddellik weer begin wegwaai' (p. 230).

Só kry groen postkolonialisme sy beslag in Etosha, só vloei bewaringsgerigte en postkoloniale perspektiewe in die roman saam om Afrikagerigte vrae te vra wat die leser nouliks kan vermy. Die roman is 'n betekenisvolle werk, beoordeel binne die konteks van die ontwikkeling van ekokritiek hier plaaslik, waar mense en hulle omgewing swaar getref is deur die impak en nadraai van die koloniale bestel.

\section{Erkenning \\ Mededingende belange}

Die outeur verklaar hiermee dat sy geen finansiële of persoonlike verbintenis het met enige party wat haar voordelig of nadelig kon beïnloed het in die skryf van hierdie artikel nie.

\section{Literatuurverwysings}

Ashcroft, B., Griffiths, G. \& Tiffin, H., 1989, The Empire writes back, Routledge, London.

Ashcroft, B., Griffiths, G. \& Tiffin, H., 2007, Post-colonial studies: The key concepts, Routledge, London.

Buell, L., 1995, The environmental imagination: Thoreau, nature writing, and the formation of American culture, Harvard University Press, Cambridge, MA.

Buell, L., 2005, The future of environmental criticism: Environmental crisis and literary imagination, Blackwell, Oxford.

Buell, L., Heise, U.K. \& Thornber, K., 2011, 'Literature and environment', Annual Review of Environment and Resources 36, 417-440. https://doi.org/10.1146/ annurev-environ-111109-144855

Cupido, D., 2015, 'Hai//om set to make legal history with Etosha aboriginal land claim' viewed 18 May 2016, from http://www.osisa.org/fr/node/5654

Curtin, D., 2005, Environmental ethics for a postcolonial world, Rowman \& Littlefield, Lanham.

Cilano, C. \& DeLoughrey, E., 2007, 'Against authenticity: Global knowledges and postcolonial ecocriticism', Interdisciplinary Studies in Literature and Environment 14(1), 71-88. https://doi.org/10.1093/isle/14.1.71
Dempers, A., 2010, 'Etosha meer as'n lekker storie', Volksblad, 26 Junie, p. 7.

Dobson, A., 1990, Green political thought: An introduction, Unwin Hyman, London.

Fourie, R., 2011, 'A postcolonial and ecocritical reading of Marlene van Niekerk's modern plaasroman Agaat', MA dissertation, University Gent, viewed 22 January 2017, from http://lib.ugent.be/fulltxt/RUG01/001/786/761/RUG01-001786761 2012_0001_AC.pdf

Heise, U.K., 2010, 'Afterword', in B. Roos \& A. Hunt (eds.), Postcolonial green: Environmental politics and world narratives, pp. 252-258, University of Virginia Press, Charlottesville, VA.

Huggan, G., 2004, 'Greening postcolonialism: Ecocritical perspectives', Modern Fiction Studies 50(3), 701-733. https://doi.org/10.1353/mfs.2004.0067

Huggan, G. \& Tiffin, H., 2007, 'Editorial: Green postcolonialism', Interventions 9(1), 1-11. https://doi.org/10.1080/13698010601173783

Huggan, G. \& Tiffin, H., 2010, Postcolonial ecocriticism: Literature, animals, environment, Routledge, London.

Martin, J., 1994, 'New, with added ecology? Hippos, forests and environmental literacy', Interdisciplinary Studies in Literature and Environment 2(1), 134-145. https://doi.org/10.1093/isle/2.1.1

Marzec, R.P., 2007, An ecological and postcolonial study of literature: From Daniel Defoe to Salman Rushdie, Palgrave Macmillan, New York.

Meyer, S., 2017, 'Mens-plantverbintenisse in Die sideboard (2014) van Simon Bruinders', LitNet Akademies 14(1), 1-26.

Naidu, S., 2014, 'Crimes against nature: Ecocritical discourse in South African crime fiction', Scrutiny2 19(2), 59-70.

Porritt, J., 1984, Seeing green, Blackwell, Oxford.

Roos, B. \& Hunt, A., 2010, 'Introduction: Narratives of survival, sustainability, and justice', in B. Roos \& A. Hunt (eds.), Postcolonial green: Environmental politics and world narratives, pp. 1-14, University of Virginia Press, politics and world

Sheng-Yen, Y., 2010, 'Ravaging the earth, wasting our patrimony', in B. Roos \& A. Hunt (eds.), Postcolonial green: Environmental politics and world narratives, pp. 82-93, University of Virginia Press, Charlottesville, VA.

Smith, S., 2013, 'Ekokritiek: In gesprek met Susan Smith', LitNet Seminare en Essays, besigtig 14 Maart 2016, from http://www.litnet.co.za/ekokritiek-in-gesprek-metsusan-smith/

Smith, S., 2014, 'Die tasbaarheid en die on(aan)tasbaarheid van literatuurteorie: ekokritiek en die nuwe materialisme', besigtig 3 Junie 2016, from http://www. litnet.co.za/poolshoogte-die-tasbaarheid-en-die-onaantasbaarheid-vanliteratuurteorie-ekokritiek

Stanley, B. \& Phillips, W.D., 2017, South African ecocriticism: Landscapes, animals, and environmental justice, Oxford Handbooks Online, Oxford University Press, viewed 06 April 2017, from http://www.oxfordhandbooks.com/view/ 10.1093/oxfordhb/9780199935338.001.0001/oxfordhb-9780199935338-e-154

Steenkamp, E., 2011, 'Identity, belonging and ecological crisis in South African speculative fiction', Doctoral thesis, Rhodes University, Grahamstown.

Van Rooyen, P., 2010, Etosha, Human \& Rousseau, Kaapstad.

Viljoen, L., 2002, 'Kan die slaaf praat? Die stem van die slaaf in enkele Brink-romans', Stilet 14(2), 92-116.

Visagie, A., 2013, 'Pasmaatspesies, niemenslike diere en die omgewing: Gedagtes oor die postkoloniale ekokritiek in Suid-Afrika', LitNet Seminare en Essays, besigtig 06 August 2015, from http://www.litnet.co.za/pasmaatspesies-niemenslike-diereen-die-omgewing-gedagtes-oor-die-postkoloniale-ekokritiek

Vital, A., 2008, 'Toward an African ecocriticism: Postcolonialism, ecology and Life \& times of Michael K', Research in African Literatures 39(1), 87-106. https://doi. org/10.2979/RAL.2008.39.1.87

Woodward, W., 2003, 'Postcolonial ecologies and the gaze of animals: Reading some contemporary Southern African narratives', Journal of Literary Studies 19(3/4), 290-315. https://doi.org/10.1080/02564710308530333

Wylie, D., 2007, 'Kabbo's challenge: Transculturation and the question of a South African ecocriticism', Journal of Literary Studies 23(3), 252-270. https://doi. org/10.1080/02564710701568113 